\title{
HOLOGLEV: A HYBRID MAGNETIC LEVITATION PLATFORM INTEGRATED WITH LENSLESS HOLOGRAPHIC MICROSCOPY FOR DENSITY-BASED CELL ANALYSIS
}

\section{SUPPORTING INFORMATION}

\author{
Kerem Delikoyun ${ }^{1}$, Sena Yaman ${ }^{1}$, Esra Yilmaz ${ }^{1}$, Oyku Sarigil, Muge Anil-Inevii ${ }^{1}$, \\ Kubra Telli², Ozden Yalcin-Ozuysal ${ }^{2}$, Engin Ozcivici $^{1}$, H. Cumhur Tekin ${ }^{1,3 *}$ \\ ${ }^{1}$ Department of Bioengineering, Izmir Institute of Technology, Izmir 35430, Turkey \\ ${ }^{2}$ Department of Molecular Biology and Genetics, Izmir Institute of Technology, Izmir \\ 35430, Turkey \\ ${ }^{3}$ METU MEMS Center, Ankara 06520, Turkey \\ *Corresponding author e-mail: cumhurtekin@iyte.edu.tr
}

\section{Table of Contents}

Figure S1 | Illustration of HologLev including Raspberry Pi for image acquisition...........S3

Figure S2 | Illustration of multimodal imaging capability of hybrid platform......................S4

Figure S3 | Spatial resolution achieved with the hybrid platform using USAF 1951 optical

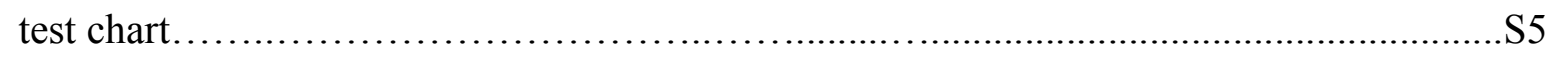

Figure S4 | Image processing pipeline for automated density measurements of cells..........S6

Figure S5 | Digital image processing of high cell concentration (i.e., $1 \times 10^{6} \mathrm{cell} / \mathrm{mL}$ ) in the

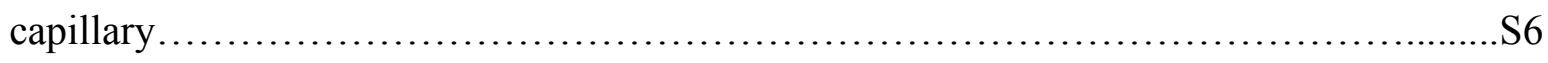

Figure S6 | Levitation analysis of microspheres using manual and automated counting for

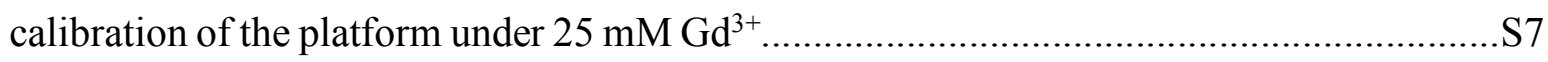

Figure S7 | The effect of $100 \mathrm{mM} \mathrm{Gd}{ }^{3+}$ paramagnetic solution on cell viability S7

Figure S8 | Brightfield and fluorescence micrographs of DMSO treated and non-treated (control) cells .S8

Figure S9 | Analysis of dead cells using density gradient centrifugation. S9 
Figure S10 | Fluorescence micrograph of dead (DMSO treated) and live MDA-MB-231 cells in the magnetic levitation platform. S9

Figure S1 1 Oil red O staining of differentiated cells used for HologLev experiments.......S10

Figure $\mathrm{S} 12 \mid$ Determination of the $\mathrm{IC}_{50}$ dose (the concentration required for $50 \%$ inhibition of cell viability) of chemotherapy drug, Docetaxel........................................ 10

Figure S13 | Levitation heights of each cell treated 48 hours with Docetaxel in 2D...........S11

Figure S14 | Reconstructed hologram of MDA-MB-231 cancer cells incubated with DMSO for $24 \mathrm{~h}$ in the magnetic levitation platform

Figure S15 | Levitation height change of microspheres with an average density of $1.05 \mathrm{~g} / \mathrm{mL}$ in an incubator platform for $24 \mathrm{~h}$ S12

Table S1 | Statistical analysis of levitation heights of microspheres with different densities $(\mathrm{g} / \mathrm{mL})$ and spiked in different $\mathrm{Gd}^{3+}$ concentrations $(\mathrm{mM})$

Table S2 | The prices of the components used for building the platform shown in Figure S1 $\mathrm{S} 13$

Video S1 | The illustration of hologram (left) and back-propagated amplitude image (right) along z-axis to evaluate in-focus image prior to computing levitation heights indicating top and bottom magnet (pink line) and interior contours of microcapillary channel (green line) 


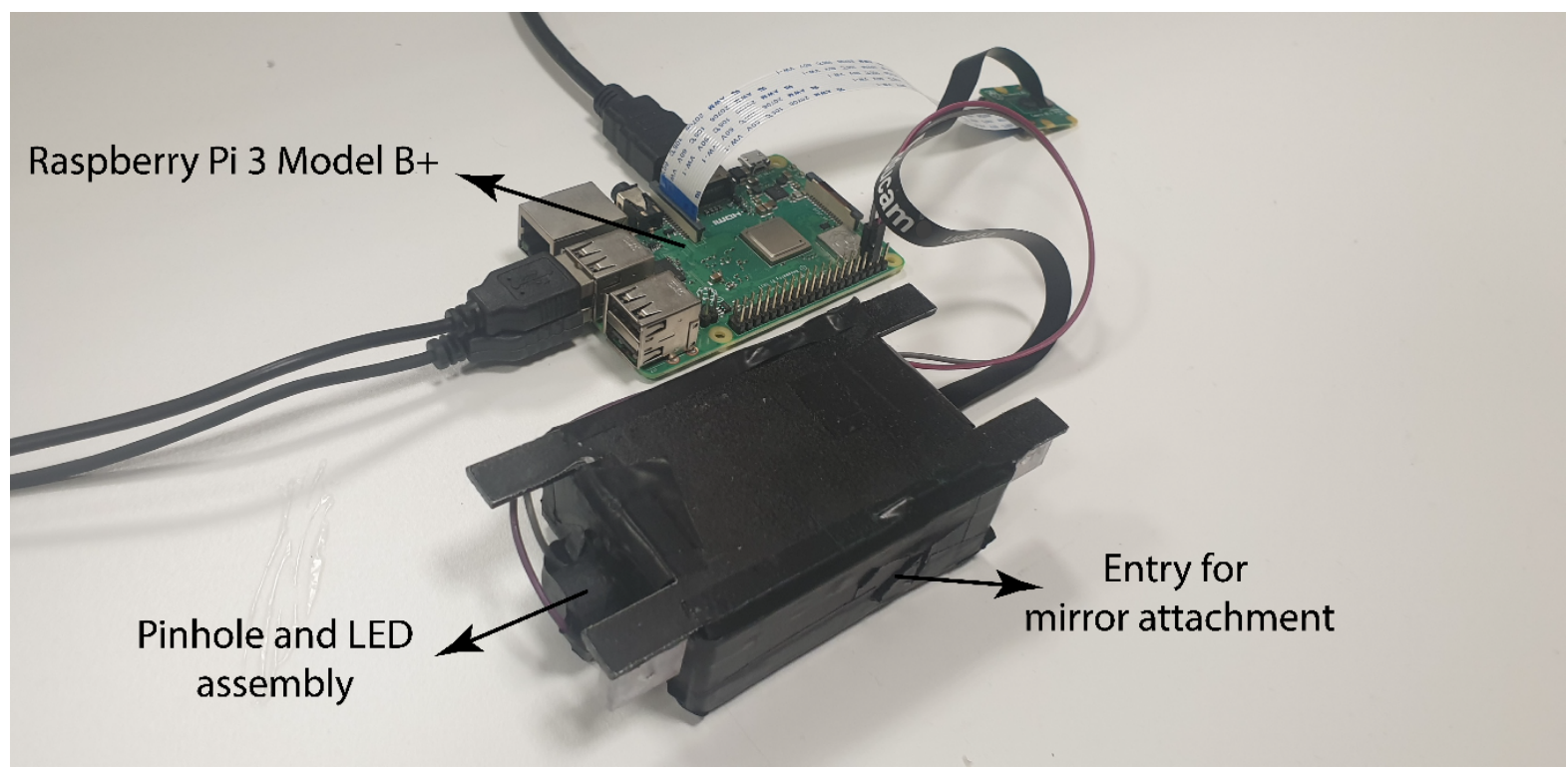

Figure S1. Illustration of HologLev including Raspberry Pi for image acquisition. 


\section{a Holographic Mode}

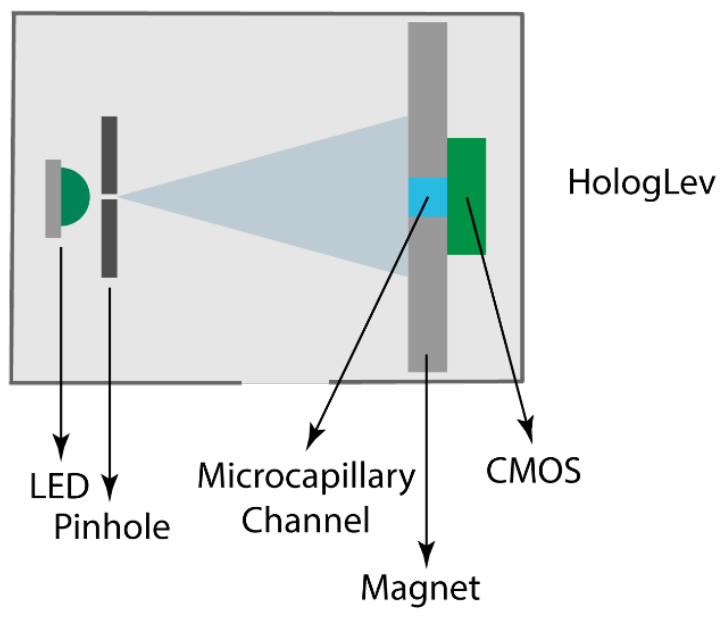

Fluorescent Microscope b Fluorescent Mode

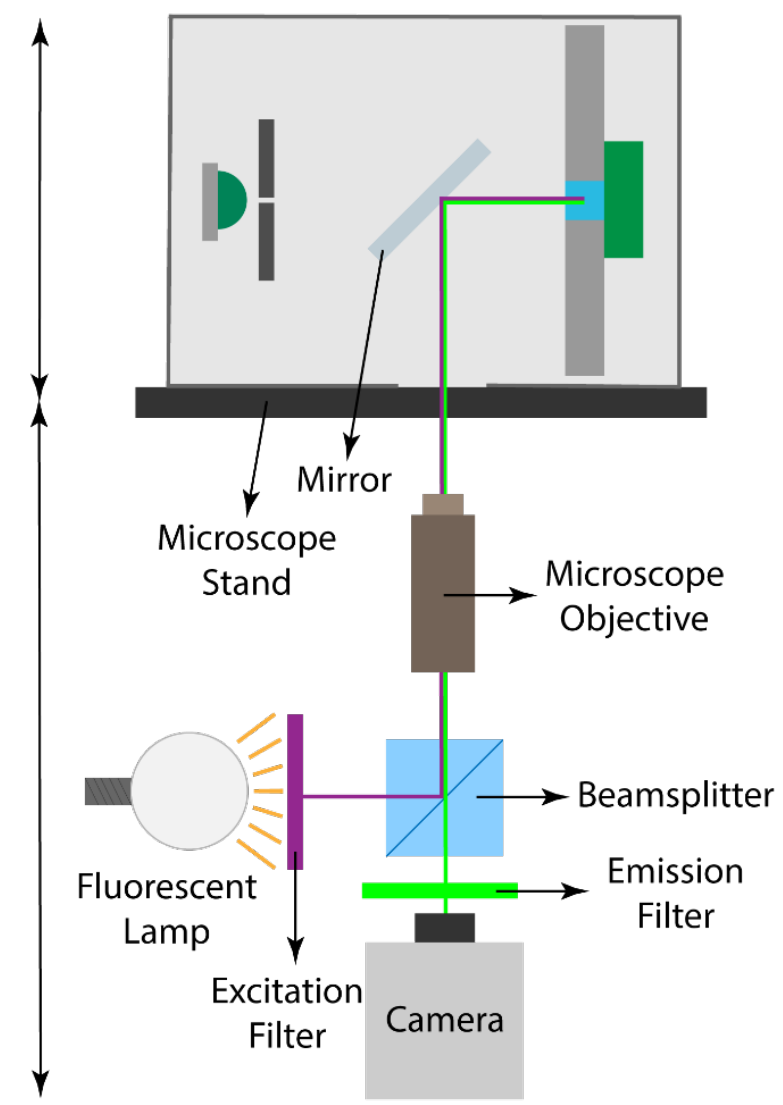

Figure S2. Illustration of multimodal imaging capability of hybrid platform. (a) Holographic mode operated with LDIHM scheme and (b) Fluorescent mode operated with a fluorescent microscope (Zeiss Axio Vert A1 with Zeiss Colibri 7 Type RGB-UV LED fluorescent illumination and Zeiss filter set FS $90 \mathrm{HE}$ ) by placing a tilted mirror between illumination scheme of LDIHM and the magnet assembly from mirror entry opening shown in Figure S1. 

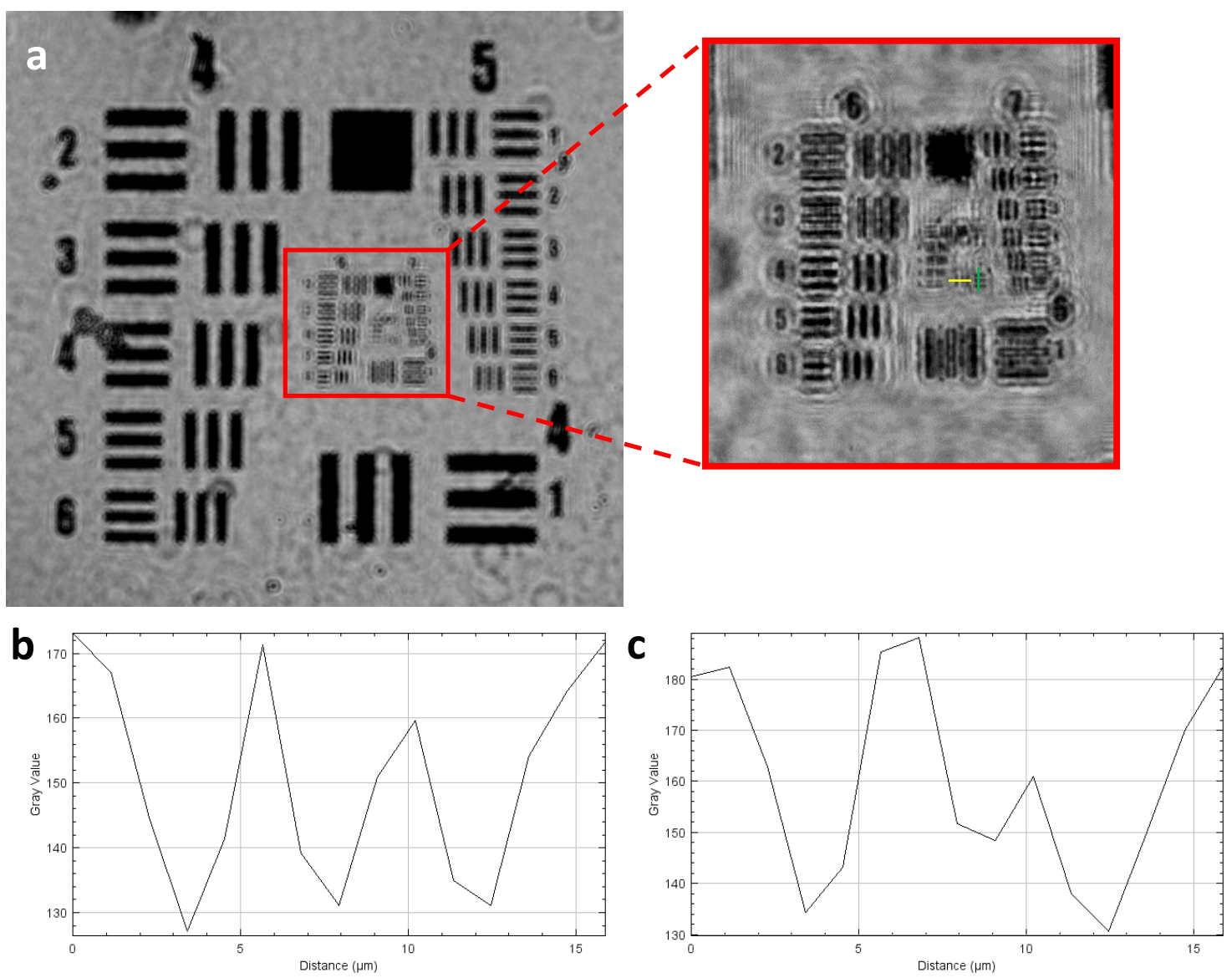

Figure S3. Spatial resolution achieved with the hybrid platform using USAF 1951 optical test chart. (a) Reconstructed image of test chart and magnified inner portion including group 8 and 9. (b, c) Intensity profile of horizontal bars (green line) and vertical bars (yellow line) on group:8 - element: 1 , respectively. 
Acquired Hologram

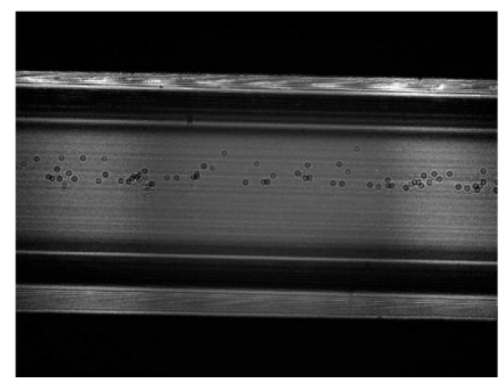

Identification of Cells

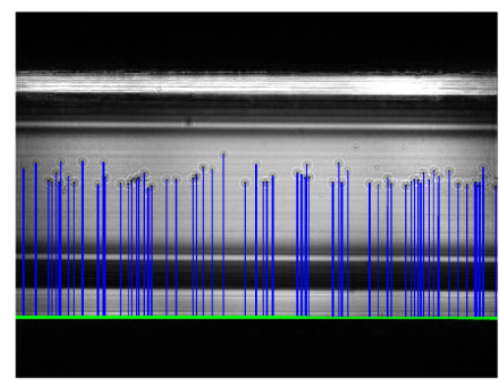

Reconstructed Amplitude

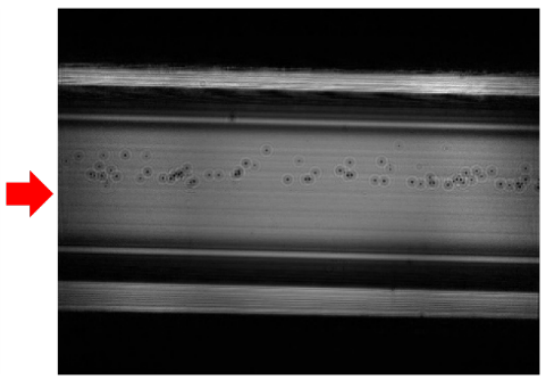

Contrast/Brightness Adjustment
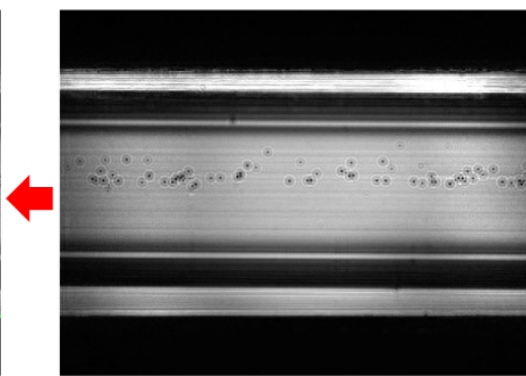

Hough Transformation

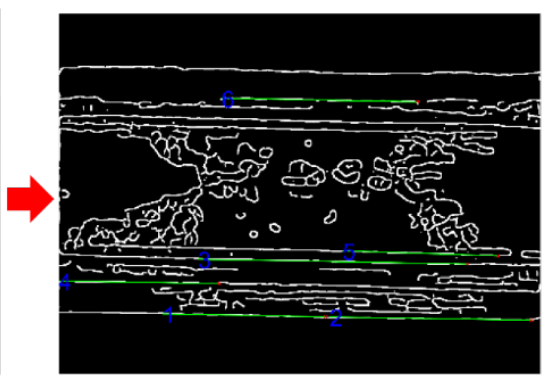

Rotated Image

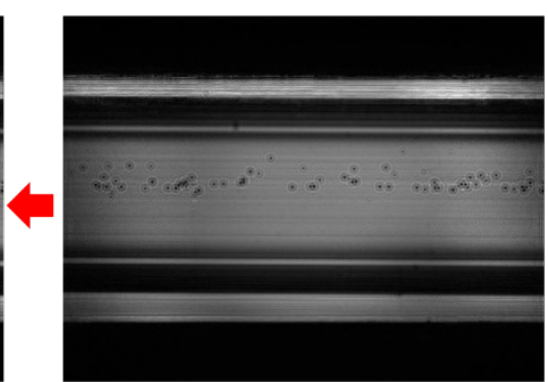

Figure S4. Image processing pipeline for automated density measurements of cells. Measured levitation height values are converted to density values from calibration curves presented in Figure 3c.

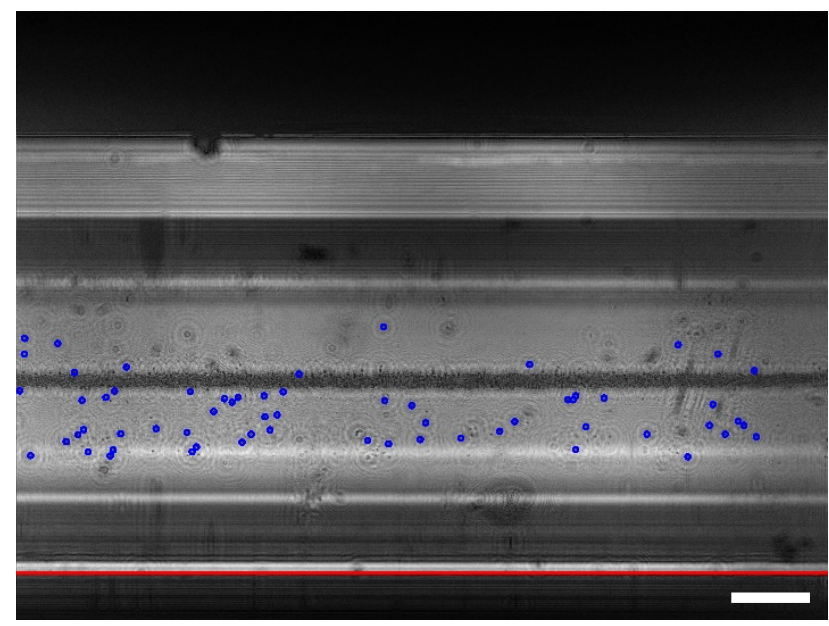

Figure S5. Digital image processing of high cell concentration (i.e., $1 \times 10^{6} \mathrm{cell} / \mathrm{mL}$ ) in the capillary. The red line indicates the bottom magnet and the scale bar is $200 \mu \mathrm{m}$. 


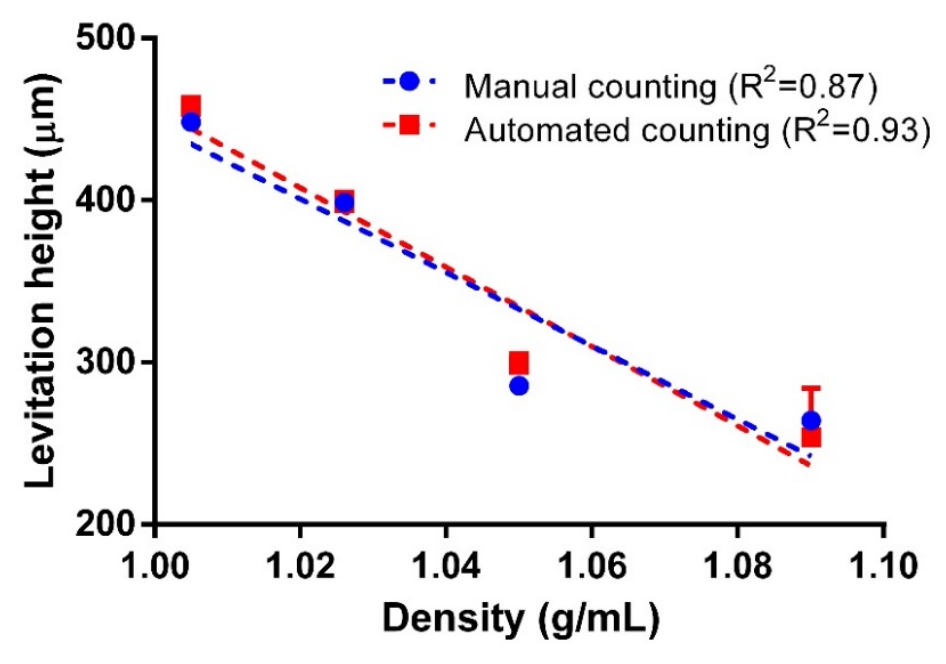

Figure S6. Levitation analysis of microspheres using manual and automated counting for calibration of the platform under $25 \mathrm{mM} \mathrm{Gd}^{3+}$. The standard equations giving levitation height $(\mathrm{h}, \mu \mathrm{m})$ vs. density $(\mathrm{d}, \mathrm{g} / \mathrm{mL})$ are $\mathrm{h}=-2266 \mathrm{~d}+2712$ and $\mathrm{h}=-2448 \mathrm{~d}+2904$ for manual and automated counting, respectively.

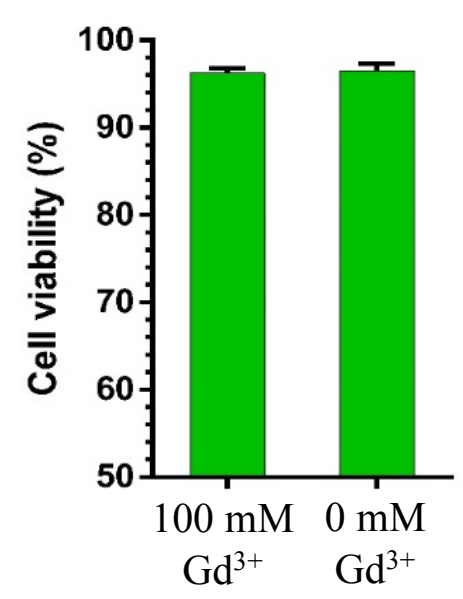

Figure S7. The effect of $100 \mathrm{mM} \mathrm{Gd}^{3+}$ paramagnetic solution on cell viability. Cells (MDAMB-231) were incubated in the corresponding $\mathrm{Gd}^{3+}$ environment for $3 \mathrm{~h}$ prior to viability analysis using Calcein AM/PI staining. No statistical difference in cell viability was observed for both cell groups. 

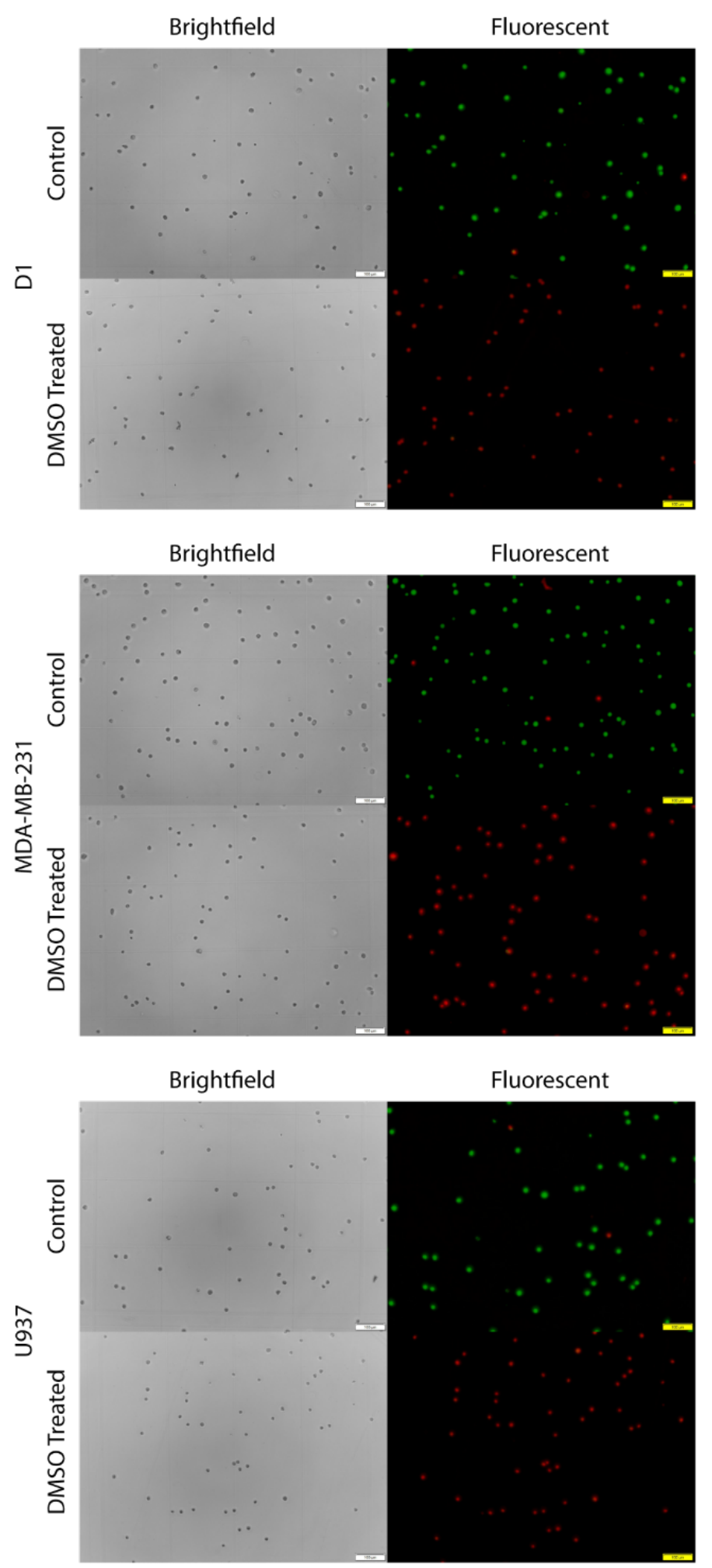

Figure S8. Brightfield and fluorescence micrographs of DMSO treated and non-treated (control) cells. Calcein AM/PI staining was conducted on cells to show live/dead cells. Scale bars are $100 \mu \mathrm{m}$. 

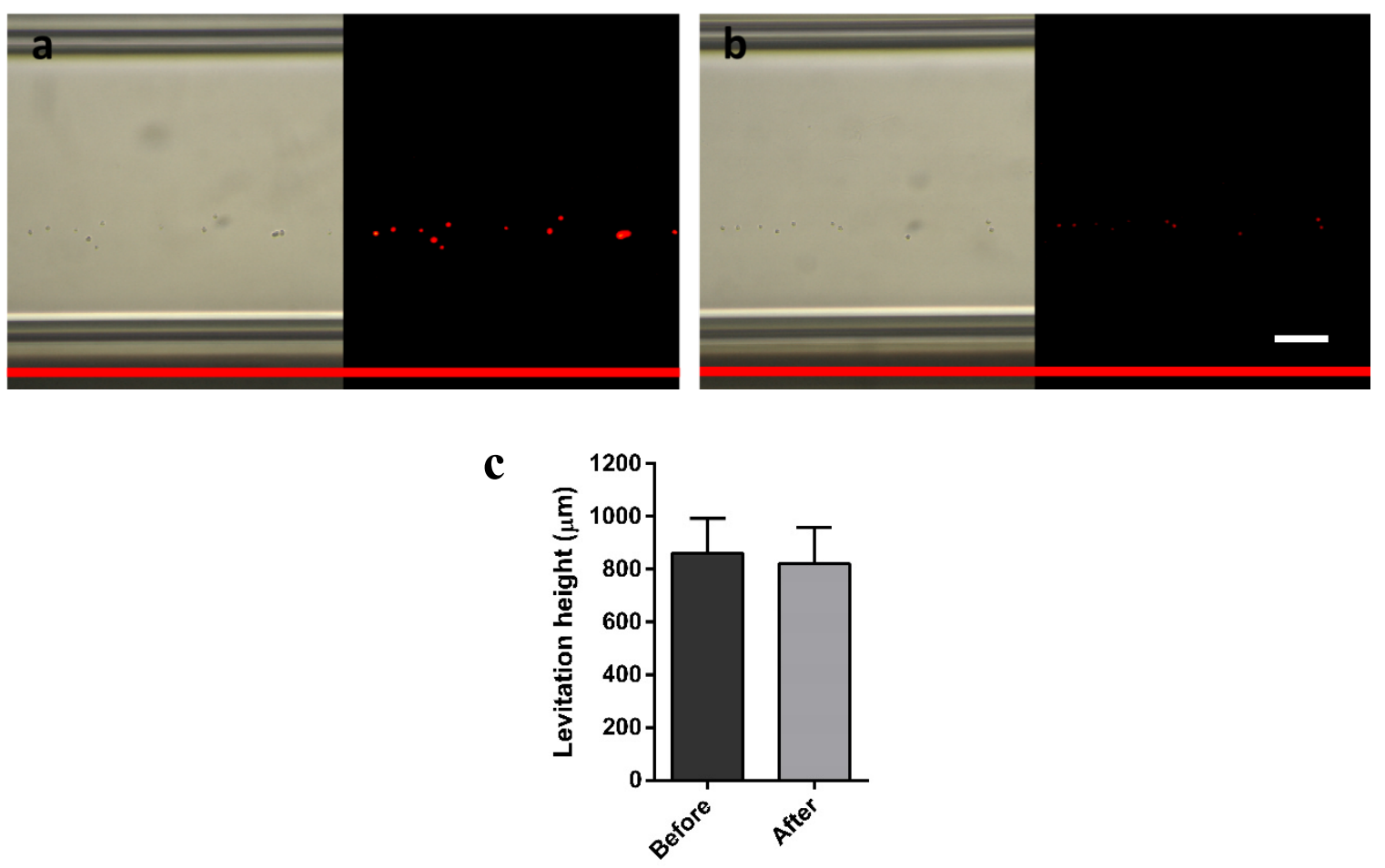

Figure S9. Analysis of dead cells using density gradient centrifugation. Levitated dead cells (a) before and (b) after of density gradient centrifugation, and (c) the mean levitation heights for each group. Ficoll PM 400 (Sigma Aldrich, Germany) was adjusted to a density of 1.15 $\mathrm{g} / \mathrm{mL}$ to separate high density cells from low density ones. No statistical difference in levitation heights was observed for both cell groups. Red lines indicate the bottom magnets and scale bar is $100 \mu \mathrm{m}$.

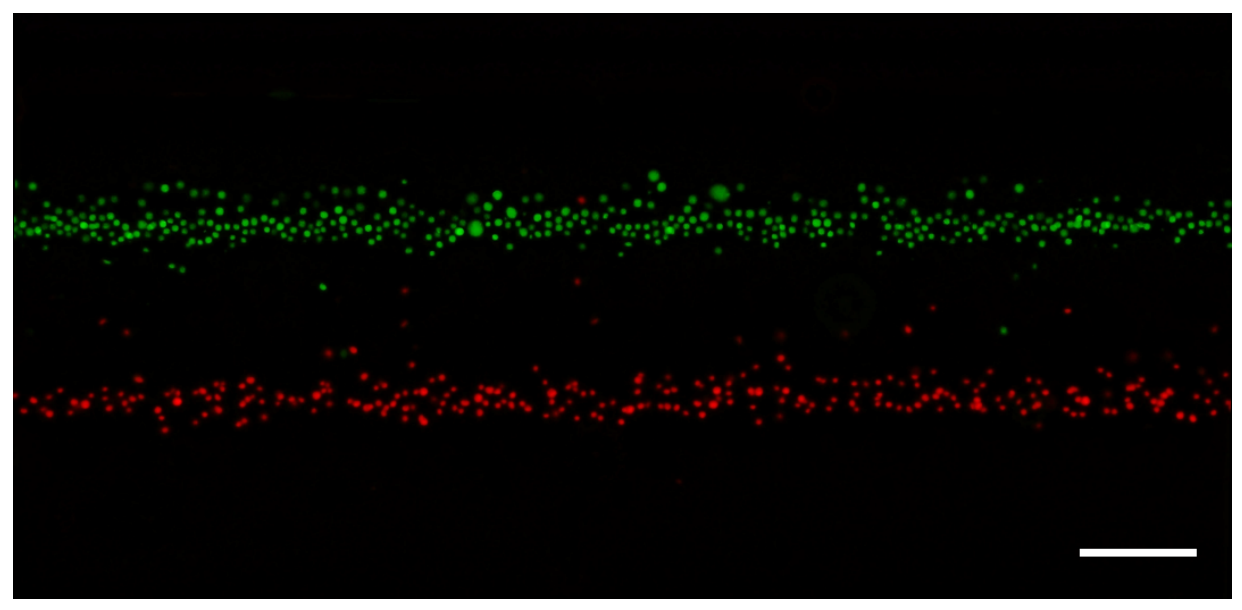

Figure S10. Fluorescence micrograph of dead (DMSO treated) and live MDA-MB-231 cells in the magnetic levitation platform. Calcein AM/PI staining was conducted on cells before the levitation. Scale bar is $200 \mu \mathrm{m}$. 


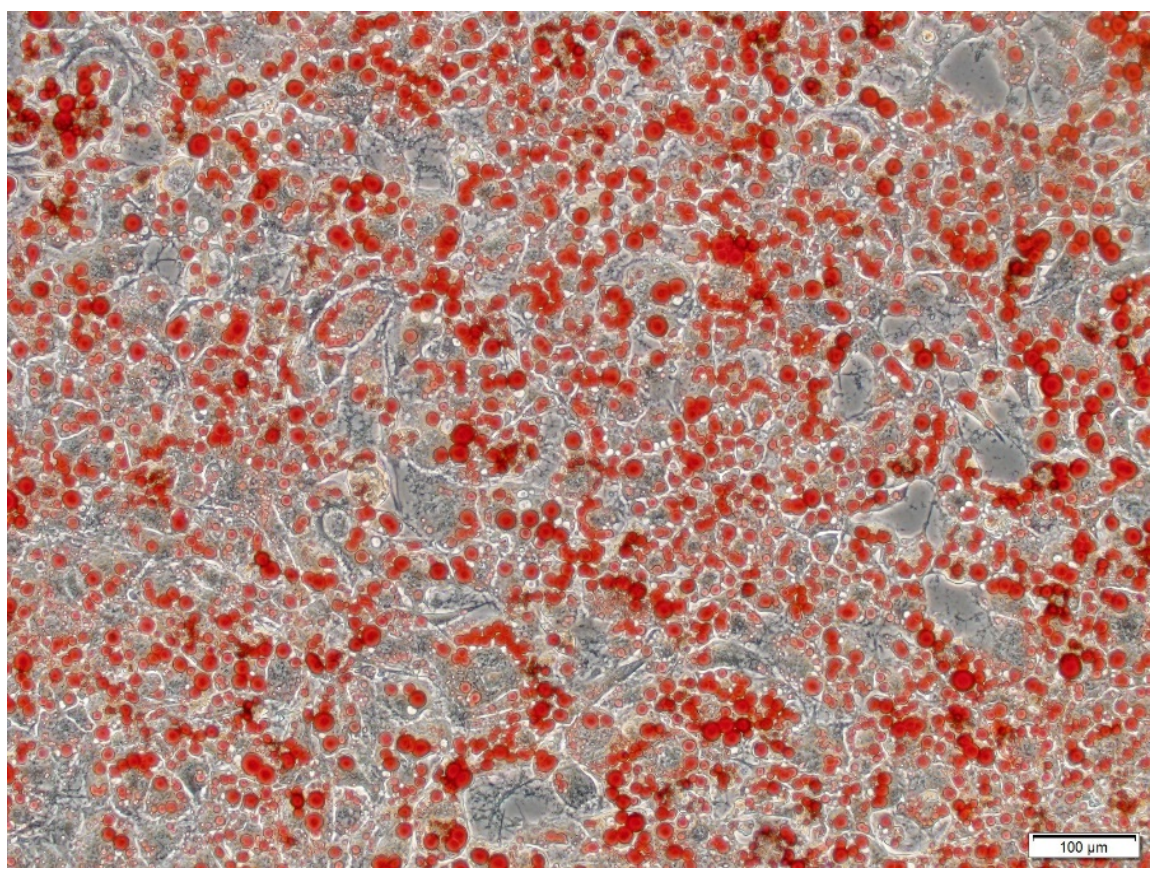

Figure S11. Oil red O staining of differentiated cells used for HologLev experiments. Cells were imaged at $10 \times$ objective. Scale bar is $100 \mu \mathrm{m}$.

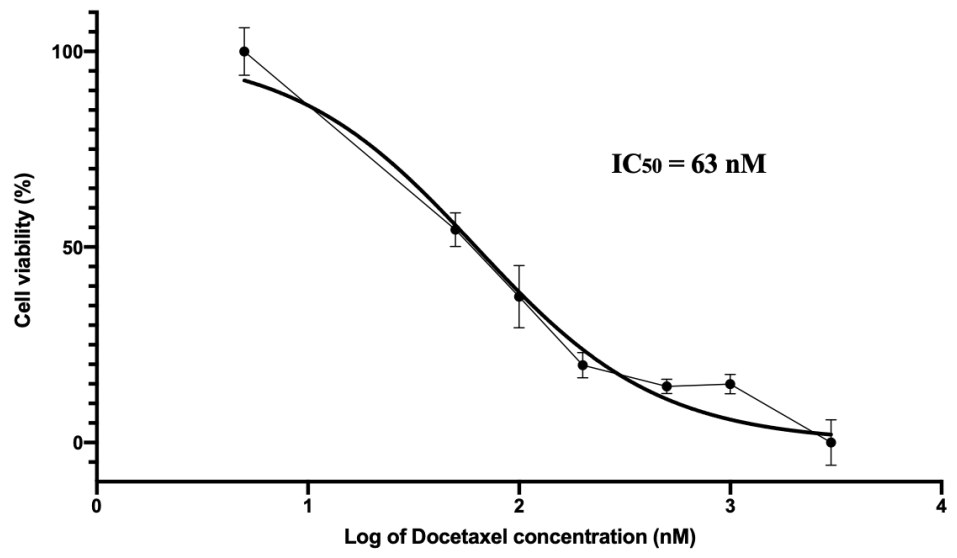

Figure S12. Determination of the $\mathrm{IC}_{50}$ dose (the concentration required for $50 \%$ inhibition of cell viability) of chemotherapy drug, Docetaxel. 


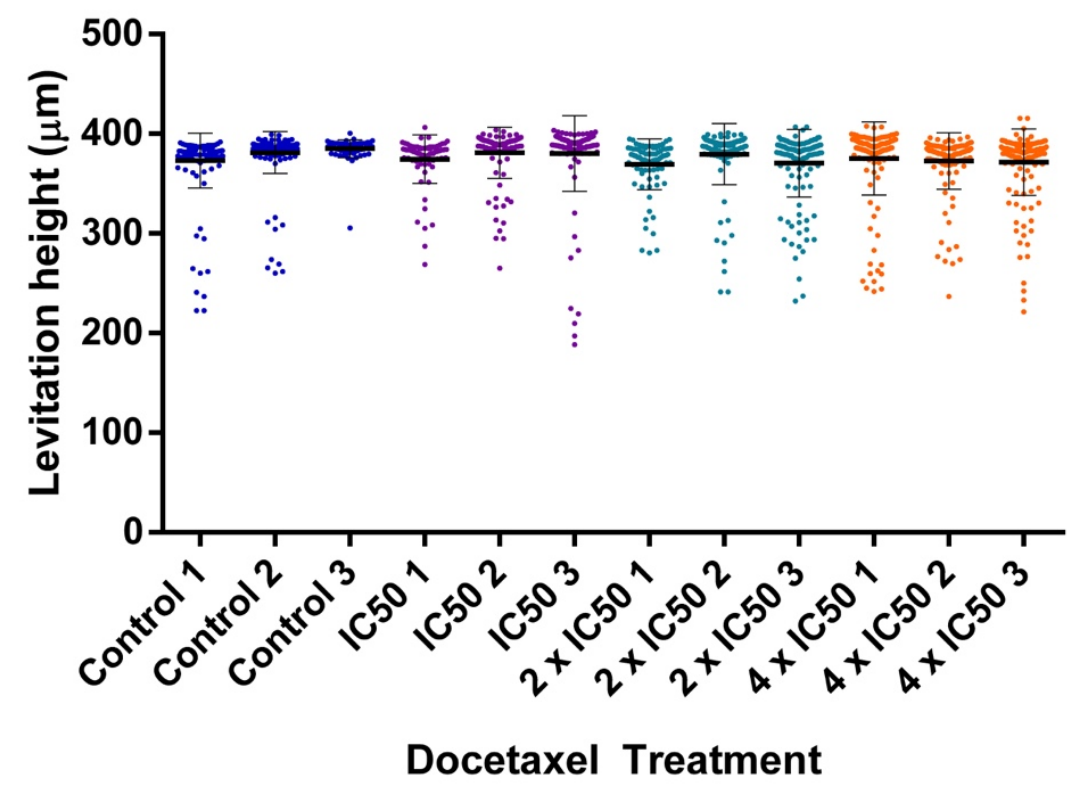

Figure S13. Levitation heights of each cell treated 48 hours with Docetaxel in 2D.

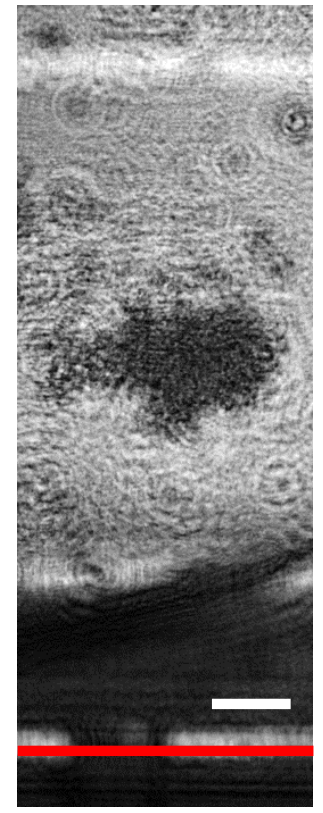

Figure S14. Reconstructed hologram of MDA-MB-231 cancer cells incubated with DMSO for $24 \mathrm{~h}$ in the magnetic levitation platform. The red line shows the bottom magnet. Scale bar: $200 \mu \mathrm{m}$. 

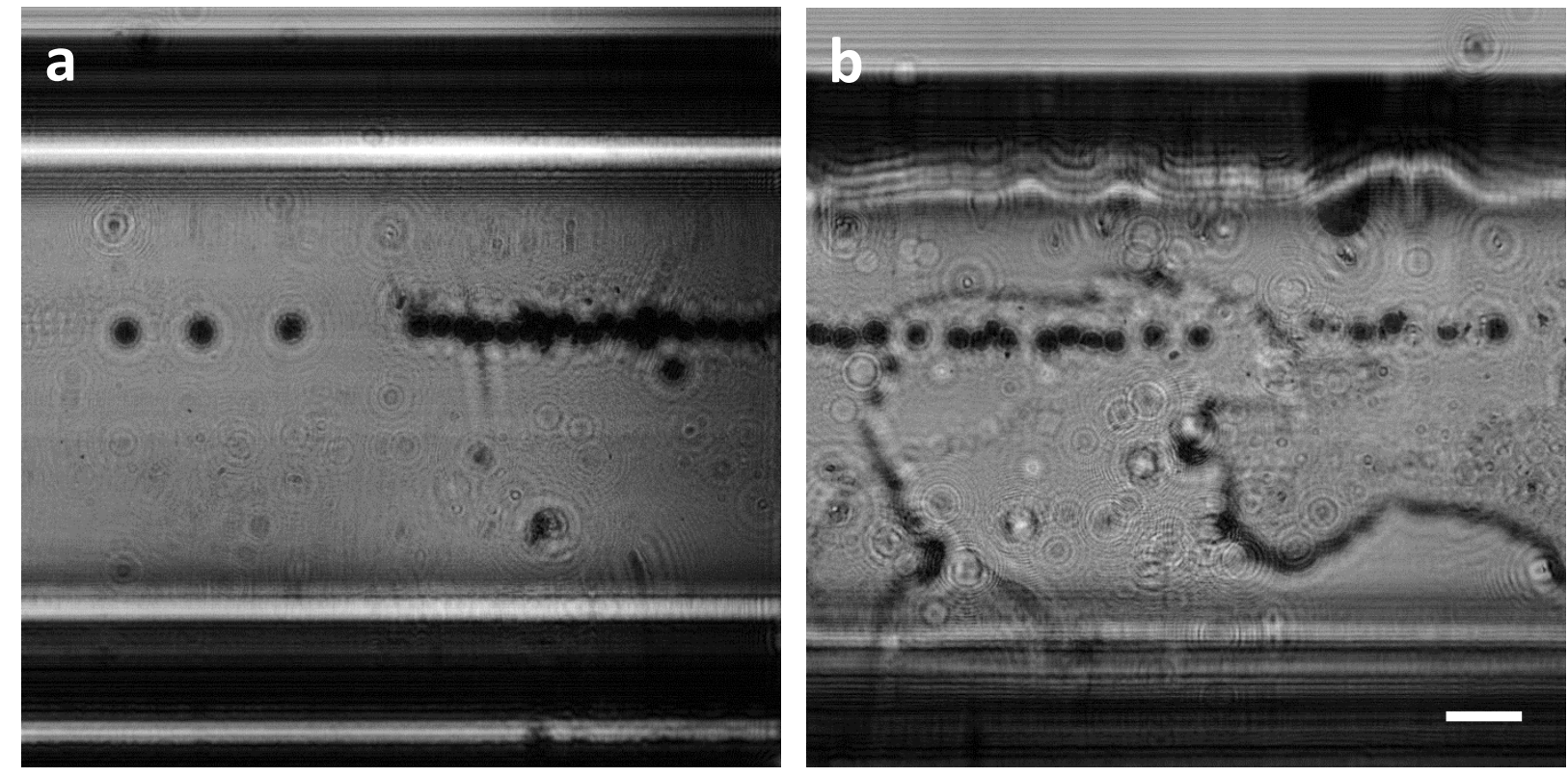

Figure S15. Levitation height change of microspheres with an average density of $1.05 \mathrm{~g} / \mathrm{mL}$ in an incubator platform for $24 \mathrm{~h}$. Acquired and reconstructed holograms at (a) 0 and (b) $24^{\text {th }}$ hour. The mean levitation height of microspheres is $393.8 \mu \mathrm{m}$ and $397.9 \mu \mathrm{m}$ at 0 and $24^{\text {th }}$ hour, respectively. Scale bar: $200 \mu \mathrm{m}$. 
Table S1. Statistical analysis of levitation heights of microspheres with different densities $(\mathrm{g} / \mathrm{mL})$ and spiked in different $\mathrm{Gd}^{3+}$ concentrations $(\mathrm{mM})$.

\begin{tabular}{|c|c|c|c|c|c|c|c|c|c|c|c|c|c|}
\hline & & \multicolumn{3}{|c|}{1.00} & \multicolumn{3}{|c|}{1.02} & \multicolumn{3}{|c|}{1.05} & \multicolumn{3}{|c|}{1.09} \\
\hline & & $25 \mathrm{mM}$ & $50 \mathrm{mM}$ & $100 \mathrm{mM}$ & $25 \mathrm{mM}$ & $50 \mathrm{mM}$ & $100 \mathrm{mM}$ & $25 \mathrm{mM}$ & $50 \mathrm{mM}$ & $100 \mathrm{mM}$ & $25 \mathrm{mM}$ & $50 \mathrm{mM}$ & $100 \mathrm{mM}$ \\
\hline \multirow{3}{*}{1.00} & $25 \mathrm{mM}$ & - & $* * * *$ & $* * * *$ & $* * * *$ & $* * * *$ & $* * * *$ & $* * * *$ & $* * * *$ & $* * * *$ & $* * * *$ & $* * * *$ & $* * * *$ \\
\hline & $50 \mathrm{mM}$ & $* * * *$ & - & $*$ & $* * * *$ & $* * * *$ & $* * * *$ & $* * * *$ & $* * * *$ & $* * * *$ & $* * * *$ & $* * * *$ & $* * * *$ \\
\hline & $100 \mathrm{mM}$ & $* * * *$ & $*$ & - & $* * * *$ & $* * * *$ & $\mathrm{nS}$ & $* * * *$ & $* * * *$ & $* * * *$ & $* * * *$ & $* * * *$ & $* * * *$ \\
\hline \multirow{3}{*}{1.02} & $25 \mathrm{mM}$ & $* * * *$ & $* * * *$ & $* * * *$ & - & $* * * *$ & $* * * *$ & $* * * *$ & $* * * *$ & $\mathrm{nS}$ & $* * * *$ & $* * * *$ & $* * * *$ \\
\hline & $50 \mathrm{mM}$ & $* * * *$ & $* * * *$ & $* * * *$ & $* * * *$ & - & $\mathrm{nS}$ & $* * * *$ & $* * * *$ & $* * * *$ & $* * * *$ & $* * * *$ & $* * * *$ \\
\hline & $100 \mathrm{mM}$ & $* * * *$ & $* * * *$ & $\mathrm{nS}$ & $* * * *$ & $\mathrm{nS}$ & - & $* * * *$ & $* * * *$ & $* * * *$ & $* * * *$ & $* * * *$ & $* * * *$ \\
\hline \multirow{3}{*}{1.05} & $25 \mathrm{mM}$ & $* * * *$ & $* * * *$ & $* * * *$ & $* * * *$ & $* * * *$ & $* * * *$ & - & $* * * *$ & $* * * *$ & $* * * *$ & $* *$ & $* * * *$ \\
\hline & $50 \mathrm{mM}$ & $* * * *$ & $* * * *$ & $* * * *$ & $* * * *$ & $* * * *$ & $* * * *$ & $* * * *$ & - & $* * * *$ & $* * * *$ & $* * * *$ & $* * * *$ \\
\hline & $100 \mathrm{mM}$ & $* * * *$ & $* * * *$ & $* * * *$ & $\mathrm{nS}$ & $* * * *$ & $* * * *$ & $* * * *$ & $* * * *$ & - & $* * * *$ & $* * * *$ & $* * * *$ \\
\hline \multirow{3}{*}{1.09} & $25 \mathrm{mM}$ & $* * * *$ & $* * * *$ & $* * * *$ & $* * * *$ & $* * * *$ & $* * * *$ & $* * * *$ & $* * * *$ & $* * * *$ & - & $* * * *$ & $* * * *$ \\
\hline & $50 \mathrm{mM}$ & $* * * *$ & $* * * *$ & $* * * *$ & $* * * *$ & $* * * *$ & $* * * *$ & $* *$ & $* * * *$ & $* * * *$ & $* * * *$ & - & $* *$ \\
\hline & $100 \mathrm{mM}$ & $* * * *$ & $* * * *$ & $* * * *$ & $* * * *$ & $* * * *$ & $* * * *$ & $* * * *$ & $* * * *$ & $* * * *$ & $* * * *$ & $* *$ & - \\
\hline & & & & & & & & & & & & \multicolumn{2}{|c|}{$\begin{array}{l}* * * *: p<0.0001 \\
* *: p<0.001 \\
*: p<0.05 \\
n S: \text { non-significan }\end{array}$} \\
\hline
\end{tabular}

Table S2. The prices of the components used for building the platform shown in Figure S1.

\begin{tabular}{|l|c|c|}
\hline \multicolumn{1}{|c|}{ Component } & Illustration & Price (\$) \\
\hline Thor Labs LED528EHP & & 3.7 \\
\cline { 1 - 1 } Pinhole $(100 \mu \mathrm{m})$ & & 2 \\
\hline 3D printed enclosure (filament) & & 2 \\
\hline 2 x NdFeB Block Magnet & & 0.5 \\
\cline { 1 - 1 } & & 40 \\
\hline Microcapillary glass channel (consumable) & & 45 \\
\hline Sony IMX219 CMOS imaging sensor & & 93.9 \\
\hline Total & & \\
\hline
\end{tabular}



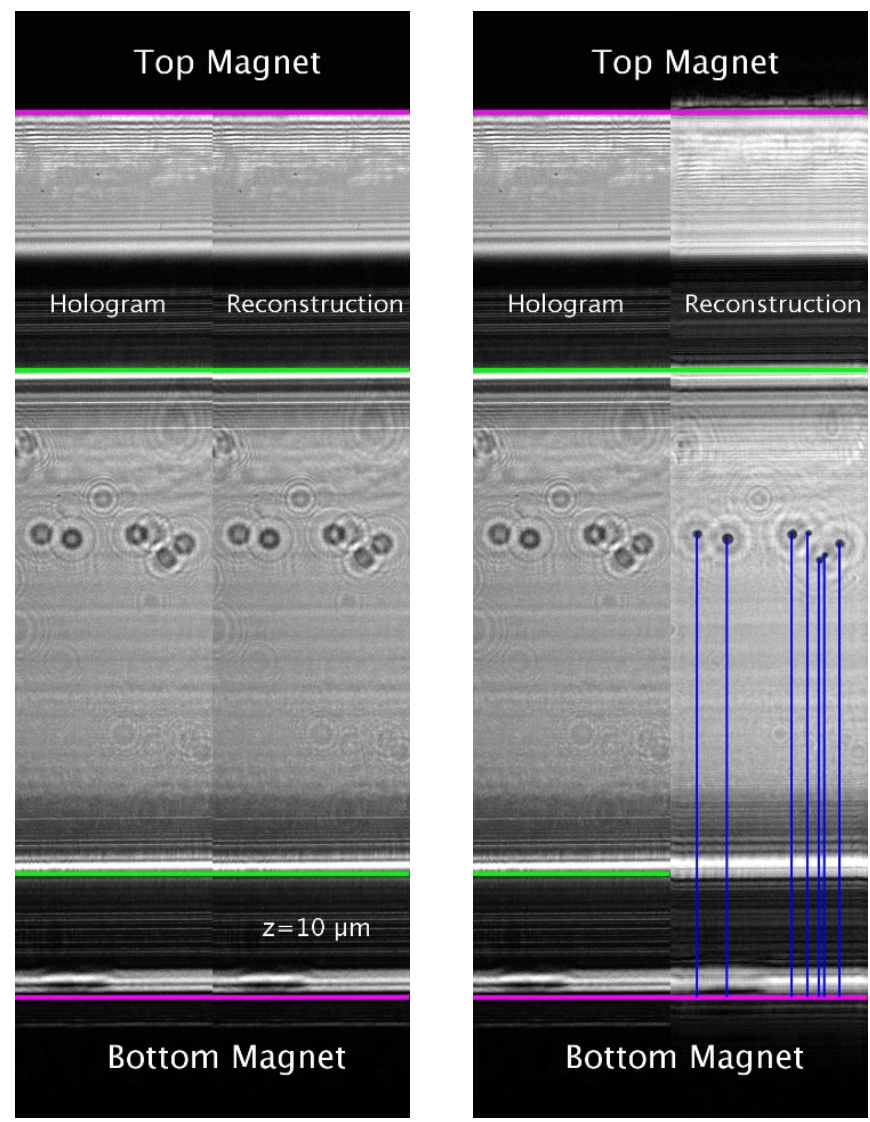

Video S1. The illustration of hologram (left) and back-propagated amplitude image (right) along z-axis to evaluate in-focus image prior to computing levitation heights indicating top and bottom magnet (pink line) and interior contours of microcapillary channel (green line). 